DOI 10.26886/2414-634X.3(39)2020.2

UDC: 728

\title{
HOUSING FOR MIGRANT WORKERS IN EU COUNTRIES
}

\section{Igor Hnes, Doctor of Architecture, Professor}

https://orcid.org/0000-0003-0810-7681

e-mail: ihor.hnes@gmail.com

\section{Volodymyr Babyak, Assistant,}

https://orcid.org/0000-0002-9672-0971

e-mail: volodymyr.babyak@gmail.com

\section{Uliana Sokolyk, student}

https://orcid.org/0000-0002-9201-7912

e-mail: uliana.sokolok@gmail.com

Lviv Polytechnic National University, Ukraine, Lviv

In the process of state development, migrant has a great influence on public life and socio-economic relations. In the system of migration processes the leading role is played by labor migration, which is realized in the form of labor migration. The object of the study is housing for migrant workers. The subject of the study is the impact of labor migration on the living standards of workers. The main goal is to summarize where and how many Ukrainian migrant go and identify the three most popular countries, to find out where Ukrainian workers live better, and why do they their homeland?

Key words: migrant worker, dwelling, housing for migrants, city workers, rental housing.

Гнесь І. П., доктор архітектури, профресор; Баб'як В. І., асистент; Соколик У. С., Житло для заробітчан в країнах ЄС / Національний університет «Львівська політехніка», Україна, Львів. 
В процесі розвитку держави великий вплив на суспільне життя та суспільно - економічні відносини має міграція. У системі міграційних прочесів провідну роль відіграє міграція робочої сили, яка реалізується у формі трудової міграції. Об'єктом дослідження є житло для трудових мігрантів. Предметом дослідження виступає вплив трудової міграції на рівень життя заробітчан. Головною метою $є$ підсумувати куди та скільки виїжджає українських мігрантів і визначити три найпопулярніші країни [таблиця 1,ст.2], щоб дізнатися де краще живеться українським заробітчанам, та чому ж вони покидають свою Батьківщину?

Ключові слова: трудовий мігрант, житло, житло для мігрантів, міські працівники, орендне житло

Вступ. Країни Європейського Союзу у 2018 році видали громадянам інших країн 3,225 млн. перших дозволів на проживання, 3 них - 527 тис. отримали громадяни України [2] Таким чином Україна посіла перше місце за дозволами проживання в країнах $\epsilon C$, повідомляє Євростат. Як зазначається, українці отримали дозвіл на проживання у країнах ЄС переважно з міркувань працевлаштування. Причому число виданих дозволів на проживання - це не кількість працюючих за кордоном українців. Вид на проживання видається на п'ять років. Отже, кожен рік ще понад півмільйона наших співгромадян приєднується до тих, хто виїхав на заробітки до країн ЄС раніше. В дану статистику враховано також біженців, котрі проходять процес юридичного визнання, але вже перебувають в країнах ЄС, працюють та винаймають певне житло. На відміну від України, дана категорія біженці також потають перед самостійним вибором помешкання. [1]

Тож вияснимо чому ж українці покидають свою Батьківщину? Потоки трудових мігрантів постійно змінюється, що залежить насамперед від політики на ринку праці приймаючих країн. 
Їдуть усі, навіть працівники без кваліфікації можуть легко знайти вакансії з більш високим заробітком, ніж в Україні. Хороші умови праці, можливість швидко заробити непогані гроші і криза в своїй країні - все це змушує людей шукати роботу за кордоном все більше.

Статистику по кількості українських заробітчан у країнах наведено у Таблиці 1. [6].

Велика частка українців скористалася безвізом прямуючи до країн $\epsilon C$.

Кількість емігрантів з України в країнах ЄС

Таблиця 1

\begin{tabular}{|l|c|c|}
\hline Країна & Тис. & $\%$ \\
\hline Польща & 694 & 35 \\
\hline Угорщина & 248 & 12 \\
\hline Чехія & 236 & 12 \\
\hline
\end{tabular}

Проаналізуємо рівень проживання українських заробітчан у країнах наведених у Таблиці 1.

Житло для заробітчан в Польщі. Більшість заробітчан не мають спеціальних навичок, а тому беруться працювати різноробочими. В основному це фрізична праця: сільськогосподарські роботи, робота на підприємствах, робота на будівництві. Для того, щоб уявити картину як живуть українці на заробітках, я поспілкувалась із декількома заробітчанами особисто. Володимир Скипко зі Львова їде на будівництво вже вдруге. За словами Володимира, житло надає роботодавець - « я виконую будівельні та оздоблювальні роботи - де працюю там і живу, кімнати без меблів, сан - вузол чи кухня є, але які умови самі розумієте... ». 


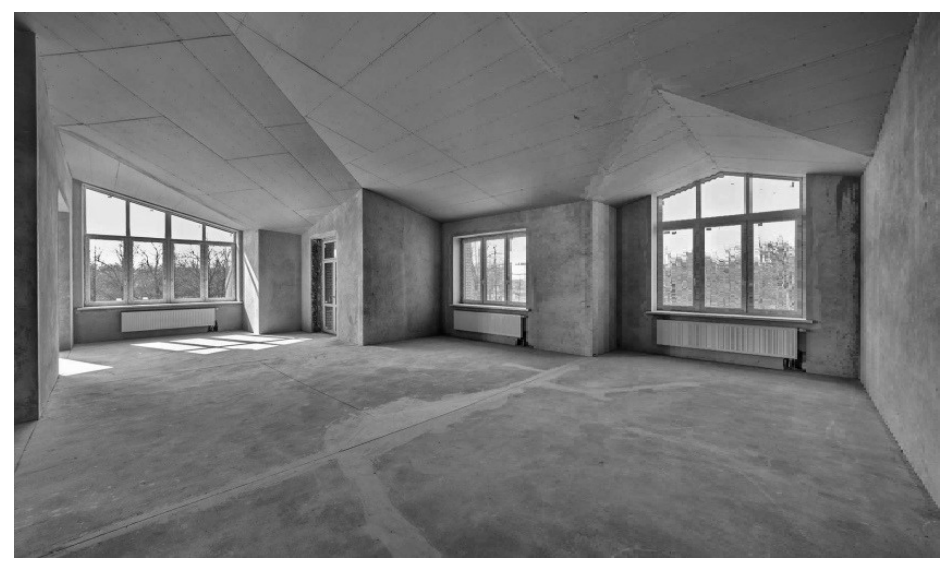

Рис. 1. Жило різноробочих у сфері будівництва

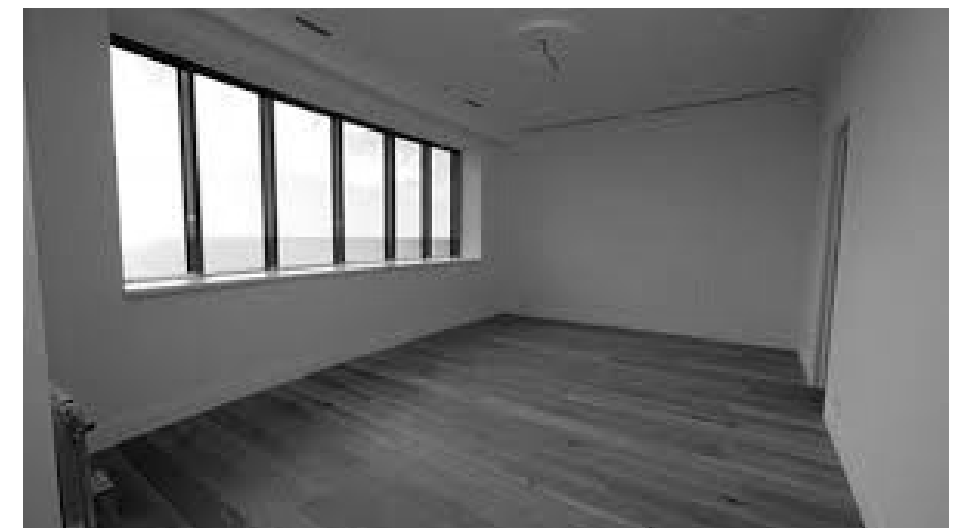

Рис. 1.1. Жило різноробочих у сфері будівництва

Звісно якщо працювати доводиться на великому підприємстві, то компанія забезпечує житлом своїх співробітників. Надається однодво- три- спальна кімната площею 12-14 м², з власним санвузлом та кухнею. Якщо потенційний роботодавець не зможе надати вам житло, $\epsilon$ можливість оренди. Орендувати квартиру у великих та популярних містах, таких як Варшава, Краків чи Вроцлав, нелегко - через велику кількість охочих та високі ціни. Водночас існує декілька варіантів та можливостей знайти постійне або тимчасове житло в Польщі, зокрема: оренда кімнати в багатокімнатній квартирі, оренда однокімнатної квартири, проживання в хостелі.

Житло для заробітчан в Угорщині. Роботу в Угорщині обирають молоді та активні люди, які готові багато та ефективно 
працювати. В Угорщині переважає орендне житло. Якщо ви хочете орендувати кімнату в Будапешті то вона буде коштувати від 50000 форинтів(4 730 грн.), за місяць без комунальних послуг. Ціна на оренду комфортабельної квартири починається від 90000 форинтів (8 510 грн.), в залежності від району.

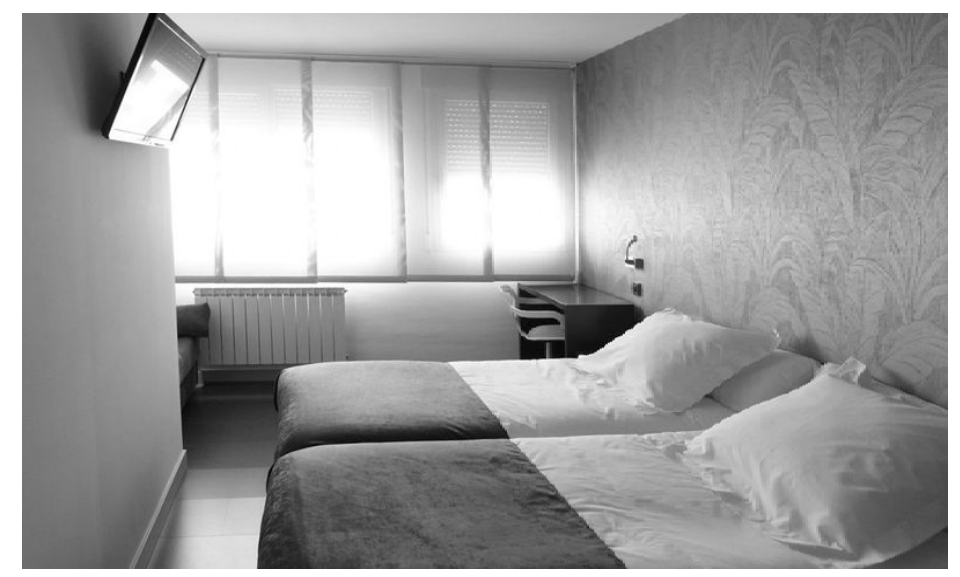

Рис. 3. Хостел як варіант поживання в Угорщині

Житло для заробітчан в Чехії. Чехія є однією з найпопулярніших країн для українських заробітчан. Вона близька географрічно і зацікавлена в іноземних працівниках. Все ж, хоча зарплата в Чехії вища, проте документи для легального працевлаштування у ній виробити важче, в порівнянні з Польщею. Вартість оренди житла в Чехії є немаленька. Наприклад, у Празі за оренду однокімнатної квартири доведеться платити від 10 тисяч крон на місяць. Трьохкімнатна тут може коштувати і 30 тисяч крон. Частіше всього в орендованій квартирі живе кілька українців, які ділять витрати між особами. Працівникам заводів пропонують житло неподалік від виробництва. У місяць воно обійдеться у 4,5-5,0 тисяч крон. При цьому кімнату треба буде ділити ще з однією, - трьома особами. Інколи роботодавці надають гуртожиток для працівників. Коштує кімната в ньому близько 3 тисяч крон і у ній також живуть 2-3 особи. 


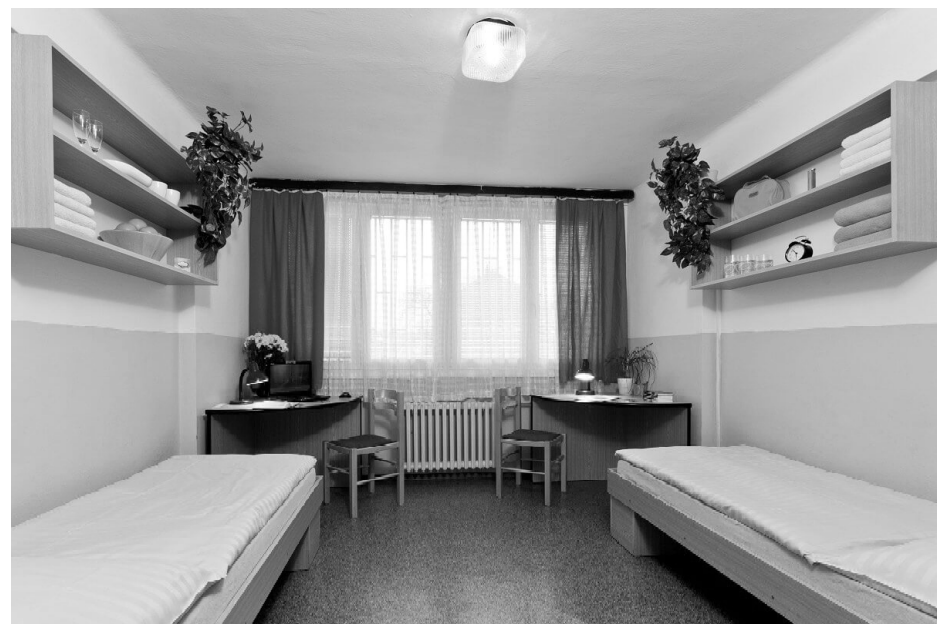

Рис. 4. Кімната у гуртожитку для працівників

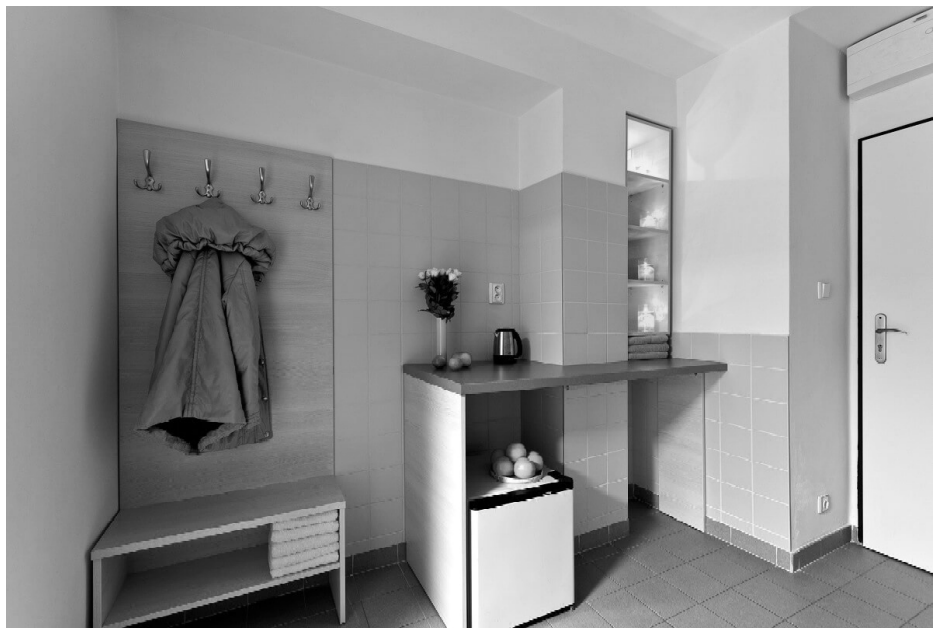

Рис. 5. Кімната у гуртожитку для працівників

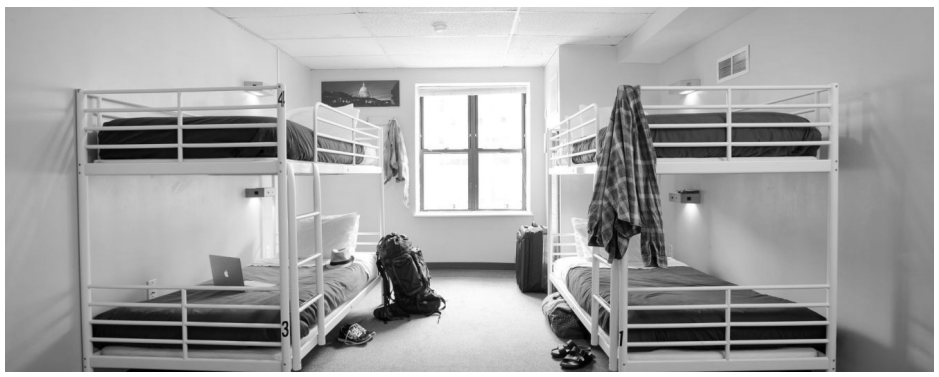

Рис. 6. Кімната у гуртожитку для працівників

Висновки: Українці прагнуть залишатися у своїй країні, але змушені заробляти на краще життя за кордоном. Значна частина їде, бо їм не вистачає грошей. Переважно це некваліфріковані працівники, які хочуть заробити більше. За кордоном їм обіцяють зарплатню від 15 тис. грн.. Люди бачать тільки цю цифру і переважно не рахують 
видатки на життя й умови проживання. Отже, Польща - ця країна дуже лояльно ставиться до прийому українців та бажаючих заробити. Як бачимо з вище сказаного [ст.3] житло в Польщі для заробітчан є, але для некваліфрікованих працівників його рівень комфрортності дуже низький. Тому, якщо вже обирати роботу в Польщі потрібно орієнтуватись, або шукати підприємства з нормальними умовами для життя, або ж особисто шукати варіанти для проживання. У Чехії, працюють тисячі українських емігрантів. Українські заробітчани беруться за будь яку роботу і часто змушені працювати в м'яко сказано поганих умовах для життя. Але уряд країни щороку покращує рівень життя для заробітчан, створюючи багато нових проектів соціального типу житла. В Угорщині дуже проблематично знайти житло з нормальними умовами за економічно-вигідною ціною. Крім економічних, але досить приємних хостелів, і орендного типу житла в Угорщині більше варіантів немає [3,4,5].

\section{תimepamypa:}

1.Баб'як В.І. Досвід та особливості формування пунктів тимчасового розміщення біженців в Україні. <https://int-konf.org/ru/2014/pitannyasuchasnoji-nauki-i-osviti-29-31-07-2014/828-bab-yak-v-i-dosvid-taosoblivosti-formuvannya-punktiv-timchasovogo-rozmishchennyabizhentsiv-v-ukrajini (2018, лютий, 25)

2. Євростат: Українці перші в ЄС отримали посвідки на проживання/ <https://www.ukrinform.ua/rubric-society/2805925-ukrainci-posili-persemisce-za-dozvolami-na-prozivanna-v-es-evrostat.html (2019, жовтень, 25)

3. Куди поїхати на заробітки за кордон? Найпопулярніші країни. <https://trydes.org/uk/kudi-poihati-na-zarobitky/ (2019, листопада, 29) 
4. Топ-5 кран, які раді емігрантам зУкрани. <https://tsn.ua/ukrayina/top-5krayin-kudi-naykrasche-bigti-z-ukrayini.html (2011, листопад, 09)
5. Українці
B
$\epsilon C$ :
міграція
без
кордонів.

<https://www.radiosvoboda.org/a/24417325.html (2011, грудень, 10)

6.2 мільйони українців скористалися безвізом прямуючи до країн $€ C$. <https://dpsu.gov.ua/ua/news/2-milyoni-ukrainciv-skoristalisya-bezvizompryamuyuchi-do-krain-S/ (2019, січень, 03)

\section{References:}

1. Bab'iak V.I. Dosvid ta osoblyvosti formuvannia punktiv tymchasovoho rozmishchennia bizhentsiv $v$ Ukraini. [Babyak V.I. Experience and peculiarities of forming temporary accommodation points for refugees in Ukraine]. Retrieved from https://int-konf.org/ru/2014/pitannya-suchasnojinauki-i-osviti-29-31-07-2014/828-bab-yak-v-i-dosvid-ta-osoblivostiformuvannya-punktiv-timchasovogo-rozmishchennya-bizhentsiv-v-ukrajini (2018, February, 25)

2. Yevrostat: Ukraintsi pershi $v$ YeS otrymaly posvidky na prozhyvannia [Eurostat: Ukrainians were the first in the EU to receive residence permits]. (2019, October, 25)

3. Kudy poikhaty na zarobitky za kordon? Naipopuliarnishi krainy. [Where to go to earn money abroad? The most popular countries]. Retrieved from http://trydes.org/uk/kudi-poihati-na-zarobitky/ (2019, June, 29)

4. Top-5 kran, yaki radi emihrantam zUkrany. [Top 5 faucets that welcome immigrants from Ukraine]. Retrieved from http://tsn.ua/ukrayina/top-5krayin-kudi-naykrasche-bigti-z-ukrayini.html (2011, June, 09)

5. Ukraintsi $v$ YeS: mihratsiia bez kordoniv. [Ukrainians in the EU: migration without borders]. Retrieved from https://trydes.org/uk/kudi-poihati-nazarobitky/ (2011, December,10) 
6. 2 miliony ukraintsiv skorystalysia bezvizom priamuiuchy do krain YeS. [2 million Ukrainians took advantage of visa-free travel to EU countries]. Retrieved from https://dpsu.gov.ua/ua/news/2-milyoni-ukraincivskoristalisya-bezvizom-pryamuyuchi-do-krain-S/ (2019, January, 03)

Citation: Igor Hnes, Volodymyr Babyak, Uliana Sokolyk (2020). HOUSING FOR MIGRANT WORKERS IN EU COUNTRIES. Innovative Solutions in Modern Science. 3(39). doi: 10.26886/2414-634X.3(39)2020.2

Copyright: Igor Hnes, Volodymyr Babyak, Uliana Sokolyk (C). 2020. This is an openaccess article distributed under the terms of the Creative Commons Attribution License (CC BY). The use, distribution or reproduction in other forums is permitted, provided the original author(s) or licensor are credited and that the original publication in this journal is cited, in accordance with accepted academic practice. No use, distribution or reproduction is permitted which does not comply with these terms. 